\title{
Phenolic acid derivatives with potential anticancer properties- a structure-activity relationship study. Part 1: Methyl, propyl and octyl esters of caffeic and gallic acids
}

\author{
S. M. Fiuza, ${ }^{a}$ C. Gomes, ${ }^{a}$ L. J. Teixeira, ${ }^{a}$ M. T. Girão da Cruz, ${ }^{\text {b,c }}$ M. N. D. S. Cordeiro, ${ }^{d}$ \\ N. Milhazes, ${ }^{\mathrm{e}, \mathrm{f}}$ F. Borges ${ }^{\mathrm{a}, \mathrm{e}}$ and M. P. M. Marques ${ }^{\mathrm{a}, \mathrm{b}, *}$ \\ 'Research Unit 'Molecular Physical-Chemistry', Coimbra University, Portugal \\ ${ }^{\mathrm{b}}$ Biochemistry Department, Coimbra University, Portugal \\ ${ }^{\mathrm{c} C e n t r e}$ for Neuroscience and Cellular Biology, Coimbra University, Portugal \\ ${ }^{\mathrm{d}}$ REQUIMTE, Chemistry Department, Faculty of Sciences, University Porto, Portugal \\ ${ }^{\mathrm{e}}$ Organic Chemistry Department, Faculty of Pharmacy, University Porto, Portugal \\ ${ }^{\mathrm{f}}$ Institute of Health Sciences-North, Gandra-Paredes, Portugal
}

Received 13 January 2004; accepted 19 April 2004

Available online 18 May 2004

\begin{abstract}
The antiproliferative and cytotoxic properties of polyphenolic acid derivatives, structurally related with the natural models caffeic and gallic acids, have been tested in human cervix adenocarcinoma cells (HeLa). Simultaneous structural information was obtained for these compounds through theoretical ab initio methods. This study was conducted for the following esters: methyl caffeate $(\mathrm{MC}, 1)$, propyl caffeate $(\mathrm{PC}, 2)$, octyl caffeate $(\mathrm{OC}, 3)$, methyl gallate $(\mathrm{MG}, 4)$, propyl gallate $(\mathrm{PG}, 5)$ and octyl gallate $(\mathrm{OG}$, 6). A significant growth-inhibition effect was assessed for some of these compounds, clearly dependent on their structural characteristics. Marked structure-activity relationships (SARs) — namely the number of hydroxyl ring substituents — were found to rule the biological effect of such systems.
\end{abstract}

(C) 2004 Elsevier Ltd. All rights reserved.

\section{Introduction}

Some naturally occurring phenolic acids and analogues, namely caffeic and gallic acids, are known to display a wide variety of biological functions, in addition to their primary antioxidant activity, which are mainly related to modulation of carcinogenesis. ${ }^{1,2}$ Indeed, many phenolic compounds have been investigated for their potential use as cancer chemopreventive agents. ${ }^{3}$ Epidemiological studies indicate that a rich diet in fruits and vegetables reduces cancer risk in humans, suggesting that certain dietary constituents may thus be effective in preventing cancer. ${ }^{4}$ Cinnamic acid esters, such as caffeic acid phenethyl (CAPE) and benzyl esters, display selective antiproliferative activity against some types of cancer

\footnotetext{
Keywords: Caffeates; Gallates; Anticancer activity; Ab initio calculations.

*Corresponding author. Tel./fax: +351-239-826-541; e-mail: pmc@ ci.ui.uc.pt
}

cells. ${ }^{5}$ CAPE, which is a component of propolis from honeybee hives, has shown anticarcinogenic and immunomodulatory properties. ${ }^{6}$ It was proposed that the molecular basis of this action may be connected to the inhibition of the nuclear transcription factor NKkappa B. ${ }^{7}$

Gallic acid and its esters, in turn, are hydroxybenzoic derivatives used as antioxidant additives in both food and pharmaceutical industry-E-310 (propyl gallate) and E-311 (octyl gallate) - which are known to protect against oxidative damage induced by reactive oxygen species (ROS), as hydroxyl radicals or hydrogen peroxide, and reactive sulfur species (RSS). ${ }^{8,9}$ Synthetic galloyl esters showed to be potent and selective enzyme inhibitors, as well as synergistic protectors against peroxyl radical damage in membranes. They were also found to inhibit cytokine-induced nuclear translocation of NF-kappa B, as well as expression of leukocyte adhesion molecules in vascular endothelium cells. ${ }^{10}$ Moreover, gallic acid derivatives are known to cause apoptosis in tumour cell lines and to inhibit lymphocyte 
proliferation. ${ }^{11}$ However, the mechanism by which gallic acid analogues induce apoptosis in some cell lines is yet not completely understood, probably involving the paradoxical generation of ROS, which interfere with the homeostatic redox balance of the cell. ${ }^{12-14}$ It is also a fact that these compounds are excellent inhibitors of protein tyrosinase kinases (PTKs). ${ }^{15}$

The recognised cytotoxic activity of phenolic derivatives depends on their rate of incorporation into cells, directly related to their lipophilicity, as much as to their antioxidant activity. Both these properties are affected by the presence of the ring substituent hydroxyl groups and by the length of the ester moiety, in polyhydroxylated phenolic esters. Thus, the knowledge of the structural characteristics of this type of compounds is of the utmost importance for the understanding of the structureactivity relationships (SARs) underlying their biological activity.

The present study concentrates on the evaluation of the growth inhibition and cytotoxic activity towards a human cancer cell line, of six distinct phenolic esters: methyl trans-3-(3,4-dihydroxyphenyl)-2-propenoate (methyl caffeate, MC, 1), propyl trans-3-(3,4-dihydroxyphenyl)2-propenoate (propyl caffeate, PC, 2), octyl trans-3-(3,4dihydroxyphenyl)-2-propenoate (octyl caffeate, OC, 3), methyl 3,4,5-trihydroxybenzoate (methyl gallate, $\mathrm{MG}$, 4), and two official antioxidants propyl-3,4,5-trihydroxy-benzoate (propyl gallate, PG, 5) and octyl-3,4,5trihydroxybenzoate (octyl gallate, OG, 6). The results thus obtained were interpreted in the light of structural information yielded by theoretical (ab initio) methods.

\section{Results and discussion}

Six distinct phenolic esters were studied-MC (1), PC (2), OC (3), MG (4), PG (5) and OG (6) (Fig. 1). These compounds, to be assessed for their antitumour activity in a human cervix adenocarcinoma cell line (HeLa), differ mainly in the number of hydroxyl ring substituent groups and/or in the length of the alkyl side chain, apart from the nature of the side carbon chain-with or without an ethylenic spacer (depending on whether they are caffeates or gallates).

\subsection{Structural analysis}

In order to determine the effect of the structural characteristics of this kind of phenolic derivatives on their antiproliferative and/or cytotoxic activity, theoretical calculations were carried out, using ab initio methods. A complete geometry optimisation was carried out for compounds 1-6, in order to obtain the distinct possible structures for these molecules, as well as their relative stability. The effect of several geometrical parameters on the overall stability of the compounds was investigated, namely: (i) orientation of the phenolic substituents, both relative to the ring and to the $\mathrm{C}=\mathrm{O}$ group - dihedrals
$\left(\mathrm{H}_{17} \mathrm{O}_{8} \mathrm{C}_{5} \mathrm{C}_{4}\right),\left(\mathrm{H}_{18} \mathrm{O}_{7} \mathrm{C}_{6} \mathrm{C}_{5}\right)$ and $\left(\mathrm{H}_{20} \mathrm{O}_{14} \mathrm{C}_{1} \mathrm{C}_{6}\right)$ equal to $0^{\circ}$ or $180^{\circ}$ (Fig. 1); (ii) position of the aromatic ring and the carbonyl group relative to the spacer $\mathrm{C}=\mathrm{C}$ bond, in the caffeates - either trans or cis, for dihedral $\left(\mathrm{O}_{12} \mathrm{C}_{11}\right.$ $\mathrm{C}_{10} \mathrm{C}_{9}$ ) equal to $0^{\circ}$ or $180^{\circ}$, respectively; (iii) orientation of the alkyl chain relative to the benzene ring, in the case of gallates $-\left(\mathrm{C}_{10} \mathrm{C}_{9} \mathrm{C}_{3} \mathrm{C}_{2}\right) 0^{\circ}$ or $180^{\circ}$ - and to the spacer double bond, in the caffeates - dihedral $\left(\mathrm{O}_{13} \mathrm{C}_{11} \mathrm{C}_{10} \mathrm{C}_{9}\right)$ equal to $0^{\circ}$ or $180^{\circ}$. For all the geometries thus obtained, calculation of the harmonic vibrational frequencies was also performed, in order to determine which ones were real energy minima (conformers) in the potential energy surface.

For all caffeates and gallates under investigation investigation-MC, PC, OC, MG, PG and PG-the most stable conformers (Fig. 1) were found to display a planar geometry, probably due to the stabilising effect of $\pi$ electron delocalisation between the benzene ring and both the carbonyl group, in the gallates, or the ethylenic side chain, in the caffeates, which is favoured when they all lie in the same plane. Moreover, in the caffeates (1-3), an $E$ orientation of the ring and the $\mathrm{C}=\mathrm{O}$ group relative to the $\mathrm{C}_{9}=\mathrm{C}_{10}$ bond showed to be highly favoured. As to the variable length ester alkyl chain, a zig-zag conformation was determined to yield, in all cases, the most energetically favoured structures.

Furthermore, an identical orientation of the benzene hydroxyl substituents, always coplanar with the aromatic ring, was detected. In fact, this allows the formation of highly stabilising medium strength intramolecular $(\mathrm{O}) \mathrm{H} \cdots \mathrm{O}$ interactions $(\mathrm{O} \cdots \mathrm{H}$ distances between 211 (for caffeates) and $218 \mathrm{pm}$ (for gallates), Fig. 1). As expected, no stable geometries were obtained when the hydroxyl groups were directed towards each other. However, some conformers were found for opposite orientations of these phenolic OHs, although these were the least stable ones $(\mathrm{O} \cdots \mathrm{O}$ distances of ca. $265 \mathrm{pm})$.

The conformational results presently obtained for the caffeates and gallates studied are in perfect accordance with previously reported data on the analogous dihydroxylated and trihydroxylated carboxylic acids, namely trans-caffeic acid (trans-3-(3,4-dihydroxyphenyl)-2-propenoic acid, CA, 7) ${ }^{16}$ and trans-3-(3,4,5-trihydroxyphenyl)-2-propenoic acid. $^{17}$ Regarding the relative orientation of the ring hydroxyls and the $\mathrm{C}=\mathrm{O}$ group, for instance, it is worth noticing that the phenolic esters now investigated present an identical behaviour to similar phenolic acids: thus, while a trans orientation was found to be preferred for caffeates 1,2 and 3 - as in caffeic acid-an $S$-cis conformation was energetically favoured for the trihydroxylated esters 4,5 and $6-$ similarly to what was observed for both gallic (8) and trans-3-(3,4,5-trihydroxyphenyl)-2-propenoic acids. This is corroborated by single-crystal X-ray studies on similar systems, namely propyl, butyl and octyl gallates. ${ }^{18-20}$ In fact, both bond lengths and angles reported for the crystal, as well as intermolecular $(\mathrm{O}) \mathrm{H} \cdots \mathrm{O}$ distances, are in close agreement with the presently calculated values. 


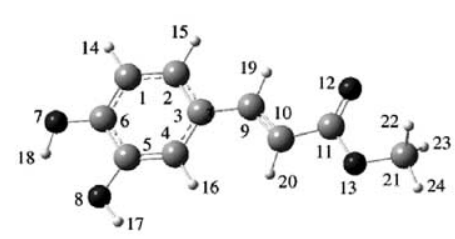

Methyl Caffeate (1)

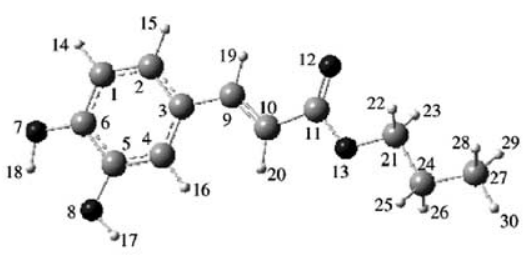

Propyl Caffeate (2)

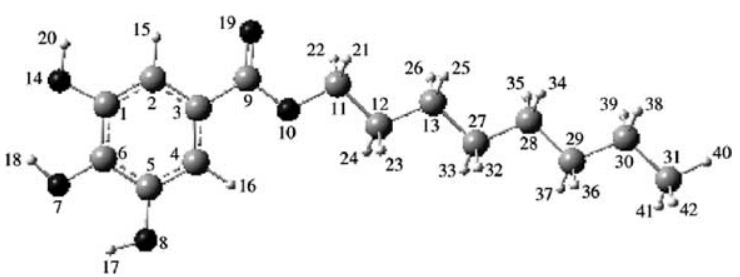

Octyl Gallate (6)

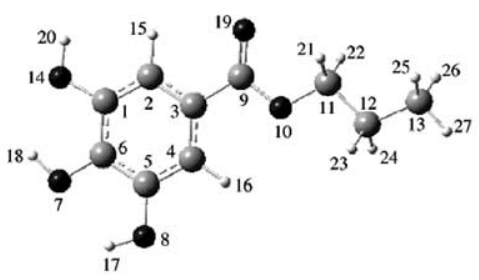

Propyl Gallate (5)

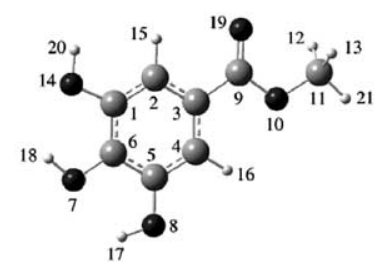

Methyl Gallate (4)

Figure 1. Optimised lowest energy geometries (B3LYP/6-31G**) for the phenolic esters studied along this work (The atom numbering is included).

\subsection{Biological assays}

The phenolic esters investigated were tested in a human cervix adenocarcinoma cell line-HeLa (epithelial-like adherent line). In order to determine the degree of toxicity of these compounds towards healthy cells, experiments were also carried out in non-neoplastic cells-fibroblasts from human embryonic lung tissue (L-132). All the results presented were obtained by two independent methods: cell density measurementTrypan blue exclusion method-and cellular viability assessment-MTT colorimetric assay. Cisplatin (cisdiaminedichloroplatinum(II), CDDP, 9) was used for comparison purposes in all the experiments carried out along this work, since it is one of the most widely used chemotherapeutic drugs in clinical practice. Caffeic and gallic acids, the di and trihydroxylated precursors of the esters under study, were also considered for comparison.

Figures 2 and 3 represent the cytotoxic effect of the caffeates and gallates tested, respectively, against the HeLa and L-132 cell lines - cell viability variation as a function of the incubation time with the drug, for different drug concentrations. From these time and doseresponse curves, it is possible to relate the structural characteristics of the compounds to their antitumour activity, thus learning on factors such as specificity of action and reversibility of the drug effect. Within the drug concentration range investigated $(25-100 \mu \mathrm{M})$, it was possible to conclude that values above $50 \mu \mathrm{M}$ did not correspond to a significant increase in the corresponding growth-inhibition effect (Fig. 2).

The cytotoxic activity of the phenolic derivatives tested showed to be strongly dependent on their structure. Actually, for each type of ester-either di or trihydroxylated - the effect of a variation in the length of the alkyl chain was found to lead to a clear change in the respective antiproliferative properties: the propyl esters ( 2 and 5) displaying a considerably more pronounced antitumoural effect towards both HeLa and L-132 cell lines than their octyl and methyl analogues (Figs. 2 and $3)$. Indeed, the compounds with a shorter alkyl chainmethyl esters 1 and 4 -showed a rather small antiproliferative effect, mainly against HeLa cells (Fig. 2). These results may be explained by the drug uptake process, which is related to the balance between its lipophilicity and hydrophilicity. Actually, for a drug to reach its site of action it must be able to interact with two different environments: lipophilic (e.g., membranes) and aqueous (e.g., cytoplasm). The lipophilicity of a phenolic ester, which is expected to increase with its alkyl chain length, ${ }^{21}$ is thus an important factor to consider, once it leads to a higher affinity for the inner (hydrofobic) part of the lipid bilayer, thus influencing the localisation of the compound within the cell. The effect of lipophilicity in the cytotoxic activity of this kind of compounds was recently reported for caffeate analogues ${ }^{22}$ : a remarkable reduction of cytotoxicity was found upon substitution of 


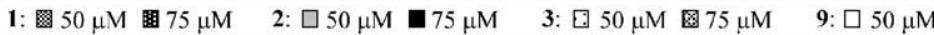

A

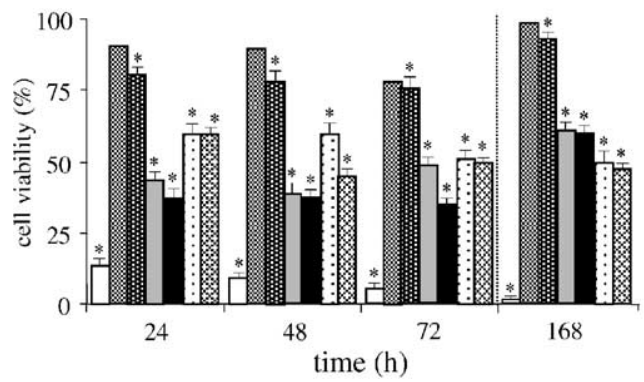

B

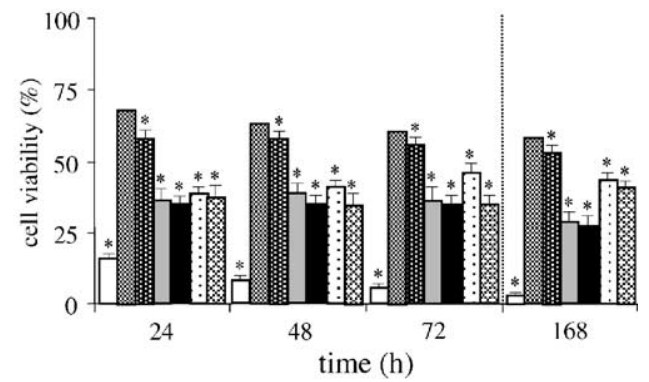

Figure 2. Time dependence of the cytotoxic effect of caffeates 1, 2 and 3 against HeLa (A) and L-132 (B) cell lines. Cells $\left(3 \times 10^{5}\right.$ cells $\left./ \mathrm{mL}\right)$ were incubated with the drugs for periods of $24-72 \mathrm{~h}$. Every $24 \mathrm{~h}$, aliquots of the cell suspensions were removed and cell viability was evaluated by the MTT colorimetric assay. In addition, the drug was removed $72 \mathrm{~h}$ after seeding and the cell viability was assessed following a further incubation of $96 \mathrm{~h}$. The data are expressed as a percentage of the control MTT reduction $(100 \%)$ and represent the average \pm mean standard deviation from two independent experiments carried out in triplicate. Intergroup comparison: ${ }^{*} p<0.05$. (Values for cisplatin (CDDP, 9) are included for comparison.)

\section{4: $50 \mu \mathrm{M} \quad$ 5: $\square 50 \mu \mathrm{M} \quad$ 6: $: 50 \mu \mathrm{M} \quad$ 9: $\square 50 \mu \mathrm{M}$}

A

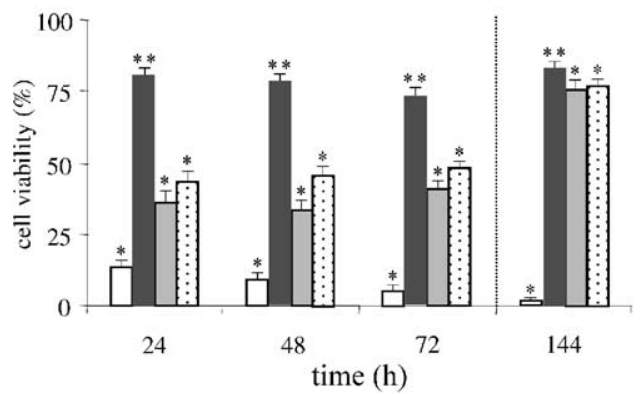

B

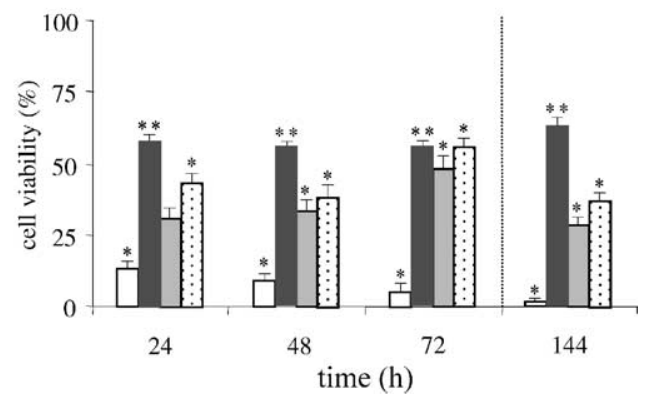

Figure 3. Time dependence of the cytotoxic effect of gallates 4,5 and 6 against HeLa (A) and L-132 (B) cell lines. Cells $\left(3 \times 10^{5}\right.$ cells $\left./ \mathrm{mL}\right)$ were incubated with the drugs for periods of $24-72 \mathrm{~h}$. Every $24 \mathrm{~h}$, aliquots of the cell suspensions were removed and cell viability was evaluated by the MTT colorimetric assay. In addition, the drug was removed $72 \mathrm{~h}$ after seeding and the cell viability was assessed following a further incubation of $72 \mathrm{~h}$. The data are expressed as a percentage of the control MTT reduction $(100 \%)$ and represent the average \pm mean standard deviation from two independent experiments carried out in triplicate. Intergroup comparison: ${ }^{*} p<0.05 ;{ }^{* *} p<0.01$. (Values for cisplatin (CDDP, 9) are included for comparison.)

the ester group by a hydrophilic moiety (either hydroxy or amide-type).

Table 1 contains the lipophilicity properties-herein defined by partition coefficients in a two-phase octanolwater system ( $\log P$ values) - calculated for the phenolic compounds under study (1-6). As expected, lipophilicity increases upon lengthening of the alkyl ester chain, and was determined to be higher for the caffeates than for the corresponding gallates. Several studies on different potential antitumour agents have shown that a maximum cytotoxic activity is often achieved for intermediate lipophilicity and water solubility values. This is also being verified by the present results, the esters yielding a higher cytotoxic activity - propyl caffeate and gallatedisplaying intermediate $\log P$ values (Table 1). A clear correlation between lipophilicity and anticancer effect, however, is not always easy to achieve, because the antiproliferative activity also depends upon other factors, such as reduction potential and structural characteristics of the compounds - for the esters presently studied, length of the alkyl chain and degree of $\mathrm{OH}$ ring substitution.
Table 1. Calculated partition coefficients $(\log P)$ and cytotoxic potency $\left(\mathrm{IC}_{50}, \mu \mathrm{M}\right)$ of compounds 1-6 towards the human cell lines HeLa and L-132 (in vitro)

\begin{tabular}{|c|c|c|c|}
\hline \multirow[t]{3}{*}{ Compound } & \multirow[t]{3}{*}{$\log P$} & \multicolumn{2}{|c|}{$\mathrm{IC}_{50}{ }^{\mathrm{a}}$} \\
\hline & & \multicolumn{2}{|c|}{ Cell line } \\
\hline & & $\mathrm{HeLa}$ & L-132 \\
\hline 1 & 1.21 & - & - \\
\hline 2 & 2.03 & 12.0 & 9.0 \\
\hline 3 & 4.60 & 70.0 & 22.0 \\
\hline 4 & 0.77 & - & - \\
\hline 5 & 1.69 & 8.0 & 10.0 \\
\hline 6 & 4.33 & 45.0 & 20.0 \\
\hline 9 & - & 2.0 & 2.0 \\
\hline
\end{tabular}

$\mathrm{IC}_{50}$ of cisplatin (9) is included for comparison purposes.

${ }^{\mathrm{a}} \mathrm{IC}_{50}$ values were calculated from dose-response curves for a drug exposure of $48 \mathrm{~h}$. (Data obtained through independent measurements of cell density and cell viability, using the Trypan blue method and the MTT assay.)

Regarding the effect of these structural characteristics, it was found that the presence and number of $\mathrm{OH}$ ring 

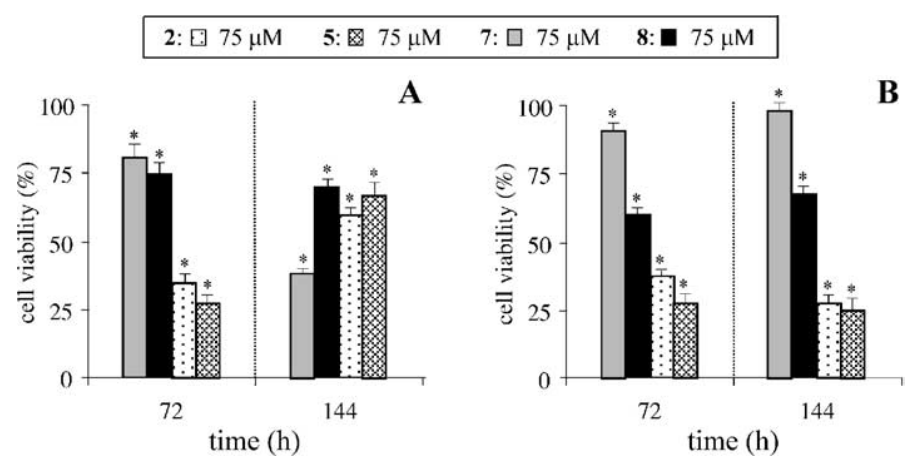

Figure 4. Plot of cell viability for compounds 2, 5, 7 and 8 against HeLa (A) and L-132 (B) cell lines. The cell viability was determined by the MTT assay, after $72 \mathrm{~h}$ of incubation with the drug. In addition, the drug was removed $72 \mathrm{~h}$ after seeding and the cell viability was assessed following a further incubation of $72 \mathrm{~h}$. The data are expressed as a percentage of the control MTT reduction (always taken as $100 \%$ ), and represent the average \pm mean standard deviation from two independent experiments carried out in triplicate. Intergroup comparison: ${ }^{*} p<0.01$.

substituents, in polyphenolic derivatives, is determinant of the corresponding biological activity. ${ }^{23,24}$ Actually, it was even reported that methylation of these hydroxyl groups, which are mainly responsible for the antioxidant characteristics of phenols, abolished cytotoxicity. ${ }^{22}$ In the present study, it was verified that, for the same length of the alkyl chain, the trihydroxylated esters displayed a higher antiproliferative and cytotoxic effect than the dihydroxylated ones - compounds 5 versus 2 (Fig. 4). This is in total agreement with previous results on several analogous phenolic acids (namely caffeic (7) and gallic (8) acids), which presented a similar behaviour in several human cancer cell lines (from leukaemia to adenocarcinomas). ${ }^{25}$

Furthermore, all the caffeates presently displaying antitumoural properties have an $E$ orientation of the aromatic ring and the $\mathrm{C}=\mathrm{O}$ group relative to the carbon chain double bond. In fact, it was previously reported by other authors that an $E$ conformation seems to be essential for the cytotoxic activity of such compounds. ${ }^{22}$ Also, the well-known ability of polyphenolic compounds to form dimeric structures ${ }^{17}$ should be taken into account, once their conformational preferences, and consequently their chemical properties, vary considerably upon dimerisation.

A significant disadvantage of the clinically used chemotherapeutic agents consists in its rather high toxicity, mainly due to side reactions with other biomolecules apart from DNA (e.g., proteins). In order to assess this factor for the compounds now investigated, experiments were carried out in non-neoplastic cells-L-132 human fibroblasts. These assays allowed to conclude that all the compounds studied present some degree of nonreversible toxicity against healthy cells, that is quite high for the propyl esters ( 2 and 5 ) for which viability decreases to about 30\% (Figs. 2-4). No significant differences have been detected between caffeates and gallates.

The values of $50 \%$ inhibitory concentration (concentration of drug yielding a $50 \%$ cell viability decrease, $\mathrm{IC}_{50}$ ) measured for the distinct compounds investigated are comprised in Table 1 . These results clearly evidence that esters 2 and 5 display a much higher cytotoxic activity towards the HeLa malignant cell line as compared to the analogous derivatives tested, displaying shorter (methyl) or longer (octyl) chains. Also, as expected, the trihydroxylated compound 5 presents a lower $\mathrm{IC}_{50}$ value than its dihydroxylated analogue 2 (8.0 vs $12.0 \mu \mathrm{M})$. Nevertheless, even these $\mathrm{IC}_{50}$ values are still higher than desirable for these phenolic derivatives to be considered as efficient antiproliferative agents. Furthermore, the effect of structural changes on the cytotoxicity of these phenolic esters was found to be much less evident for the fibroblasts than for the malignant cells tested, which may reflect a certain specificity towards neoplastic cells.

The degree of reversibility of both the antiproliferative and cytotoxic effects displayed by compounds aimed for use as antitumour drugs is, understandably, of the utmost importance. In fact, consideration of a recovery period following drug exposure, apart from allowing the determination of the reversibility of the drug effect, as well as the measurement of a possible delayed cytotoxicity, avoids over or underestimation of the level of cell kill achieved. The present results indicate that, except for the methyl derivatives (which yield a rather low cytotoxic effect), both propyl and octyl gallates display a more reversible cytotoxic activity against HeLa cells (up to ca. $75 \%$ ) than the corresponding caffeates (only up to ca. $60 \%$ ). However, cell viability recovery after drug removal was found to be higher for this cancer cell line (up to $60-75 \%$ ) than for fibroblasts (recovery up to 40 $50 \%)$.

Despite the significative toxicity of the esters under study towards fibroblasts, they were found to be far more cytotoxic towards human cancer cells (almost threefold) than the corresponding caffeic (7) or gallic (8) acids (Fig. 4), which is in accordance with previous studies on similar caffeates. ${ }^{5}$ In fact, the electrochemical behaviour of these systems - namely their electrondonating ability - was previously reported to be affected by the introduction of alkyl groups in the carboxylate part of the molecule (ester formation), ${ }^{26}$ which may explain such a marked difference in biological activity 
between the acid and the ester form of these phenolic derivatives.

\section{Conclusions}

The phenolic esters investigated for their antitumour activity in a human adenocarcinoma cell line - methyl, propyl and octyl caffeates and gallates - varied mainly in the number of phenolic substituents and/or in the length of the alkyl side chain, apart from the distance between the carboxylic group and the aromatic ring (depending on whether they were caffeates or gallates).

A structural analysis of these compounds was carried out by theoretical (ab initio) methods, once structurally different esters were found to yield distinct cell density and viability results, thus allowing the establishment of structure-activity relationships. The geometrical preferences of the compounds studied are mainly determined by electrostatic factors, as well as by the formation of both intra and intermolecular hydrogen bonds (e.g., (O)H $\cdots \mathrm{O}$ or even (C) H...O). Consequently, the most stable structures calculated for these systems displayed a clear preference for a planar geometry. In the case of caffeates, the presence of an ethylenic spacer allows the formation of a conjugated system, strongly stabilised through $\pi$-electron delocalisation.

The final aim of this type of studies is the investigation of new anticancer agents, since chemotherapeutic drugs presently used in clinical practice display a high toxicity towards healthy cells and often lead to the development of resistance. The present work allowed to conclude on the clearly higher growth inhibition and cytotoxic activity of phenolic esters as compared to their corresponding acids. Also, the effect of slight structural variations in this kind of systems was found to cause a marked change in their biological activity. In fact, di and trihydroxylated propyl esters - both caffeates and gallates-displayed a far more pronounced growthinhibition activity towards the cell lines tested than their methyl and octyl analogues. Although these particular compounds presented some drawbacks for its use as antitumour agents-namely their hardly reversible cytotoxicity towards non-cancer cells-they also displayed a good water solubility. Knowing that propyl gallate (5) and octyl gallate (6) are commonly used additives in food and pharmaceutical industry, the results presently described-evidencing a significant cytotoxic activity of compound 5 against healthy cellsshould not be disregarded.

When studying the potential antiproliferative role of this type of polyhydroxylated phenols, one should attend to properties such as size, degree of ring hydroxyl substitution and length of the alkyl chain, as well as lipophilicity. The understanding of the structure-activity relationships ruling their biological function lies in more specific assays, that target particular binding sites and mechanisms of action. This knowledge is of the utmost importance for the development of new and more effi- cient anticancer drugs, structurally based on phenolic compounds.

\section{Experimental}

\subsection{Chemicals}

Antibiotics (penicillin-streptomycin $100 \times$ solution), transcaffeic acid ([trans-3-(3,4-dihydroxyphenyl)-2-propenoic acid)], 3,4-dihydroxycinnamic acid), cisplatin (cis-diaminedichloroplatinum(II)), DMEM-HG culture medium, EDTA (ethylenediamine-tetraacetic acid, disodium salt, dihydrate), gallic acid (3,4,5-tri-hydroxybenzoic acid), glutamine, HEPES ( $N$-[2-hydroxy-ethyl]piperazine- $N^{\prime}$-[4-butane-sulfonic acid]), methanol, methyl gallate (methyl 3,4,5-trihydroxybenzoate), MTT (3[4,5-dimethyl-thiazol-2-yl]-2,5-diphenyltetrazolium bromide), phenol red (phenol-sulfonphthalein), $n$-propanol, propyl gallate (propyl 3,4,5-trihydroxybenzoate), octyl gallate (octyl 3,4,5-trihydroxybenzoate), n-octanol, Trypan blue $(0.4 \%$ solution, prepared in $0.81 \%$ sodium chloride and $0.06 \%$ dibasic potassium phosphate), trypsin, trisodium citrate, inorganic salts and acids (of analytical grade) were purchased from Sigma-Aldrich Chemical Co. (Madrid, Spain). Dimethylsulfoxide- $d_{6}$ $(99.8 \%)$ and tetramethylsilane (TMS) were obtained from E. Merck, Darmstadt, Germany. Fetal calf serum was obtained from Biochrom KG, Berlin. All other reagents and solvents were pro analysis grade, purchased from Merck (Lisbon, Portugal).

The HeLa cell line was purchased from the European Collection of Cell Cultures (ECACC, United Kingdom), while the L-132 cells were made available by the Centre of Experimental Medicine and Surgery of the University General Hospital Gregorio Marañon, Madrid (Spain).

\subsection{General synthetic procedure}

Methyl caffeate (methyl trans-3-(3,4-dihydroxyphenyl)2-propenoate, MC) and propyl caffeate (propyl trans-3(3,4-dihydroxyphenyl)-2-propenoate, PC). The propyl and methyl esters of caffeic acid were synthesised by Fischer esterification, following the procedure described by Borges and coworkers, with slight modifications: ${ }^{27,28}$ Caffeic acid $(1.0 \mathrm{~g})$ was refluxed for ca. $5 \mathrm{~h}$ with $150 \mathrm{~mL}$ of methanol or $n$-propanol, containing $2 \mathrm{~mL}$ of $\mathrm{H}_{2} \mathrm{SO}_{4}$, until the caffeic acid was no longer detected by TLC. After cooling, the solvent was partially evaporated under reduced pressure and the solution was neutralised with $10 \% \mathrm{Na}_{2} \mathrm{CO}_{3}$. The mixture was then extracted with diethyl ether $(3 \times 150 \mathrm{~mL})$. The organic phases were combined, washed with water $(3 \times 100 \mathrm{~mL})$, dried over $\mathrm{MgSO}_{4}$ and concentrated under reduced pressure. The residue was purified by column chromatography (silica gel, petroleum ether/ethyl ether). The structural data for methyl and propyl caffeates is in accordance with the results reported in the literature. ${ }^{28}$

Octyl caffeate (octyl trans-3-(3,4-dihydroxyphenyl)-2propenoate, OC). Caffeic acid (5g) and anhydrous 
dimethylformamide $(0.1 \mathrm{~mL})$ were dissolved in anhydrous ethyl ether $(30 \mathrm{~mL})$. Oxalyl chloride $(7.3 \mathrm{~mL})$ was added dropwise and the solution was stirred for $1 \mathrm{~h}$ at room temperature and another hour at $50^{\circ} \mathrm{C}$. Octanol $(6 \mathrm{~mL})$ was then added and the mixture stirred for $8 \mathrm{~h}$. After cooling, the solvent was partially evaporated under reduced pressure giving a yellowish-brown oil residue, which was dissolved in chloroform $(75 \mathrm{~mL})$. The organic phase was washed with $5 \% \mathrm{NaH}-$ $\mathrm{CO}_{3}(3 \times 100 \mathrm{~mL})$ and water $(3 \times 100 \mathrm{~mL})$ and dried over $\mathrm{MgSO}_{4}$. After solvent evaporation, the crude product was purified by column chromatography (silica gel, chloroform). The fractions containing the product were collected and crystallised (petroleum ether/chloroform) giving a white solid compound. Yield 35\%; FTIR $v_{\max }$ $\left(\mathrm{cm}^{-1}\right): 3489,3315,2954,2979,2850,1683,1624,1604$, 1530,1472 , 1441, 1309, 1281, 1241, 1177, 1154, 1107, $1031,974,815 ;{ }^{1} \mathrm{H}$ NMR $\delta: 0.85\left(3 \mathrm{H}, \mathrm{t}, J=7.1, \mathrm{CH}_{3}\right)$, $1.25\left(10 \mathrm{H}, \mathrm{s}, \mathrm{CH}_{2}\right), 1.61\left(2 \mathrm{H}, \mathrm{m}, \mathrm{CH}_{2}\right), 4.09(2 \mathrm{H}, \mathrm{t}$, $\left.J=6.6, \mathrm{OCH}_{2}\right), 6.25(1 \mathrm{H}, \mathrm{d}, J=15.9, \mathrm{H}(\alpha)), 6.75(1 \mathrm{H}$, $\mathrm{d}, J=8.0, \mathrm{H}(5)), 6.99(1 \mathrm{H}, \mathrm{dd}, J=8.2,1.9, \mathrm{H}(6)), 7.04$ $(1 \mathrm{H}, \mathrm{d}, J=1.9, \mathrm{H}(2)), 7.46(1 \mathrm{H}, \mathrm{d}, J=15.9, \mathrm{H}(\beta)), 9.20$ $(1 \mathrm{H}, \mathrm{s}, \mathrm{OH}), 9.50(1 \mathrm{H}, \mathrm{s}, \mathrm{OH}) ;{ }^{13} \mathrm{C} \mathrm{NMR} \delta: 13.9 \mathrm{CH}_{3}$, 22.1 $C \mathrm{H}_{2}, 25.4 \mathrm{CH}_{2}, 28.3 \mathrm{CH}_{2}$, 28.6. $\mathrm{CH}_{2}, 28.7 \mathrm{CH}_{2}$, $31.2 \mathrm{CH}_{2}, 114.0 \mathrm{C}(2), 114.8 \mathrm{C}(\alpha), 115.7 \mathrm{C}(5), 121.3 \mathrm{C}(6)$, $125.5 \mathrm{C}(1), 145.0 \mathrm{C}(4), 145.5 \mathrm{C}(\beta), 148.4 \mathrm{C}(3), 166.6$ $(\mathrm{C}=\mathrm{O})$; EI-MS m/z (\%): $292\left(\mathrm{M}^{+\bullet}, 60\right), 180(100) ; 163$ (57), 136 (27), 123 (16), 89 (25); mp 110-112 ${ }^{\circ} \mathrm{C}$.

\subsection{Apparatus}

Infrared spectra were recorded on an ATI Mattson Genesis Series FTIR spectrophotometer using potassium bromide disks. Only the most significant absorption bands are reported $\left(v_{\max }, \mathrm{cm}^{-1}\right) .{ }^{1} \mathrm{H}$ and ${ }^{13} \mathrm{C} \mathrm{NMR}$ data were acquired (at room temperature) on a Brüker AMX 300 spectrometer, operating at 300.13 and $75.47 \mathrm{MHz}$, respectively. Dimethylsulfoxide- $d_{6}$ was used as a solvent; chemical shifts are expressed in $\delta(\mathrm{ppm})$ values relative to tetramethylsilane (TMS) as an internal reference; coupling constants $(J)$ are given in Hz. Electron impact mass spectra (EI-MS) were carried out on a VG AutoSpec instrument. The data are reported as $\mathrm{m} / \mathrm{z}$ (\% of relative intensity of the most important fragments). Melting points were obtained on a Köfler microscope (Reichert Thermovar) and are uncorrected.

\subsection{Other conditions}

Thin-layer chromatography (TLC) was carried out on precoated silica gel 60 F254 and cellulose plates (E. Merck). The layer thickness was 0.2 and $0.1 \mathrm{~mm}$, respectively. The following systems were used for analytical control: silica gel, petroleum ether/diethyl ether/ formic acid (5:5:0.1); silica gel, chloroform/methanol/ formic acid (9:1:0.5); cellulose, water/acetic acid (9:1). The spots were visualised under UV detection (254 and $366 \mathrm{~nm}$ ) and iodine vapour. Solvents were evaporated in a Buchi Rotavapor.

\subsection{Preparation of solutions}

All compounds studied were water soluble in the concentration range used-from $2.5 \times 10^{-5}$ to $1.0 \times 10^{-4} \mathrm{M}$. Solutions were prepared in phosphate buffered saline solution (PBS): $132.0 \times 10^{-3} \mathrm{M} \mathrm{NaCl}, 4.0 \times 10^{-3} \mathrm{M} \mathrm{KCl}$; $1.2 \times 10^{-3} \mathrm{M} \quad \mathrm{NaH}_{2} \mathrm{PO}_{4} ; 1.4 \times 10^{-3} \mathrm{M} \quad \mathrm{MgCl}_{2} ; 6.0 \times$ $10^{-3} \mathrm{M}$ glucose; $1.0 \times 10^{-2} \mathrm{M}$ HEPES ( $N$-[2-hydroxyethyl]piperazine- $N^{\prime}$-[4-butane-sulfonic acid]). Fresh solutions were prepared monthly and kept from light, in order to prevent oxidation. Trypan blue was used as a $0.04 \%(w / v)$ solution in PBS. MTT (3-[4,5-dimethylthiazol-2-yl]-2,5-diphenyl-tetrazolium bromide) was prepared, in a concentration of $0.5 \mathrm{mg} / \mathrm{mL}$, in PBS solution containing $1.0 \times 10^{-3} \mathrm{M} \mathrm{CaCl}_{2}$.

\subsection{Ab initio MO calculations}

Full geometry optimisation and calculation of the harmonic vibrational frequencies-were performed using the GAUSSIAN $98 \mathrm{~W}$ program, ${ }^{29}$ within the density functional theory (DFT) approach, in order to properly account for the electron correlation effects (particularly important in this kind of systems). The widely employed hybrid method denoted by B3LYP, ${ }^{30-35}$ which includes a mixture of HF and DFT exchange terms and the gradient-corrected correlation functional of Lee, Yang and Parr, ${ }^{36,37}$ as proposed and parametrised by Becke, ${ }^{38,39}$ was used, along with the double-zeta split valence basis set 6-31G**.40,41 Molecular geometries were fully optimised by the Berny algorithm, using redundant internal coordinates $^{42}$ : The bond lengths to within ca. $0.1 \mathrm{pm}$ and the bond angles to within ca. $0.1^{\circ}$. The final root-meansquare (rms) gradients were always less than $3 \times 10^{-4}$ hartree bohr ${ }^{-1}$ or hartree radian ${ }^{-1}$. No geometrical constraints were imposed on the molecules under study.

\section{7. $\log P$ calculations}

Estimated partition coefficients were calculated according to Parham et al. ${ }^{43}$

\subsection{Biological assays}

Cell culture: Stock cultures of cells were maintained at $37^{\circ} \mathrm{C}$, under $5 \% \mathrm{CO}_{2}$. HeLa, and L-132 (grown in monolayers) were kept in Dulbecco's modified Eagle's high glucose $(4500 \mathrm{mg} / \mathrm{L})$ medium (DMEM-HG), supplemented with $10 \%$ heat-inactivated fetal calf serum, glutamine $(1.168 \mathrm{~g} / \mathrm{L})$ and antibiotics (100 units of penicillin and $100 \mathrm{mg}$ streptomycin). The cell lines were subcultured twice a week. HeLa cells were harvested using a dissociation medium composed of $136.9 \times 10^{-3} \mathrm{M} \mathrm{NaCl}, 2.7 \times 10^{-3} \mathrm{M} \mathrm{KCl}, 8.2 \times 10^{-3} \mathrm{M}$ $\mathrm{Na}_{2} \mathrm{HPO}_{4}, 1.5 \times 10^{-3} \mathrm{M} \mathrm{KH} \mathrm{PO}_{4}, 4.0 \times 10^{-4} \mathrm{M}$ EDTA (ethylene-diaminetetraacetic acid, disodium salt, dihydrate) ( $\mathrm{pH} 7.4$ ) and containing $0.0004 \%$ (w/v) phenol red. L-132 cells were harvested with a trypsin/ EDTA solution $(0.05 \%$ trypsin, $0.35 \mathrm{mM}$ EDTA.4Na, 
reconstituted in balanced salt solution without $\mathrm{Ca}^{2+}$ or $\left.\mathrm{Mg}^{2+}\right)$.

\subsection{Toxicity and cell growth inhibition evaluation}

Cytotoxicity and cell density evaluation after drug exposure - for drug concentrations between $2.5 \times 10^{-5}$ to $1.0 \times 10^{-4} \mathrm{M}-$ was assessed with use of standard assays. Cells were plated at $5 \times 10^{5} \mathrm{cell} / \mathrm{mL}$. Twenty four hours after seeding, drug solutions were added to the medium and the cultures were incubated at $37^{\circ} \mathrm{C}$. Cells were harvested and analysed (both in controls and in drugtreated cultures) every $24 \mathrm{~h}$, for a total period of 3 days. Reversibility of the drug effect was tested by removing the drug and adding fresh culture medium in the last day of incubation with the drug, and assessing the cell viability following three to four more days of incubation. Cell density and viability were determined by Trypan blue exclusion on single-cell suspensions obtained from the monolayer cultures. Cell viability was further assessed by mitochondrial dehydrogenase activity-MTT assay. ${ }^{44} 47$ Measurements were carried out each $24 \mathrm{~h}$ and the results expressed as a percentage of the control (nontreated) cells, which was always taken as 100\%. All experiments were performed in triplicate.

The 50\% inhibitory concentration (concentration of drug required to inhibit cell growth by $50 \%, \mathrm{IC}_{50}$ ) was calculated, for each compound tested, from doseresponse curves (for an incubation period of $48 \mathrm{~h}$ ).

\subsection{Statistical analysis}

All experiments were performed in triplicate. The results are expressed as mean values $\pm \mathrm{SD}$, (the corresponding error bars being displayed in the graphical plots). Statistical analysis were performed using ANOVA, followed by post hoc test of Fisher's Protected Least Significant Difference. Statistical comparison between the data was based on the Pearson correlation coefficient, values less than 0.05 being considered as significant.

\section{Acknowledgements}

L.J.T. acknowledges financial support from FCT - $\mathrm{PhD}$ fellowship SFRH/BD/8580/2002. The authors thank the Centre of Experimental Medicine and Surgery of the University General Hospital Gregorio Marañon, Madrid, Spain (in the person of Dr. Maria Concepción Guisasola Zululeta), for the kind offer of the L-132 cell line.

\section{References and notes}

1. Rao, C. V.; Desai, D.; Rivenson, A.; Simi, B.; Amin, S.; Reddy, B. S. Cancer Res. 1995, 55, 2310.
2. Leu, T. H.; Maa, M. C. Curr. Med. Chem. Anti-Canc. Agents 2002, 2, 357.

3. Tapiero, H.; Tew, K. D.; Ba, G. N.; Mathe, G. Biomed. Pharmacother. 2002, 56, 200.

4. Mahmoud, N. N.; Carothers, A. M.; Grunberger, D.; Bilinski, R. T.; Churchill, M. R.; Martucci, C.; Newmark, H. L.; Bertagnolli, M. M. Carcinogenesis 2000, 21, 921.

5. Nagaoka, T.; Banskota, A. H.; Tezuka, Y.; Saiki, I.; Kadota, S. Bioorg. Med. Chem. 2002, 10, 3351.

6. Nomura, M.; Kaji, A.; Ma, W.; Miyamoto, K.; Dong, Z. Mol. Carcinog. 2001, 31, 83.

7. Etzenhouser, B.; Hansch, C.; Kapur, S.; Selassie, C. D. Bioorg. Med. Chem. 2001, 9, 199.

8. Masak, H.; Okamoto, N.; Sakaki, S.; Sakurai, H. Biol. Pharm. Bull. 1997, 20, 304

9. Klein, E.; Weber, N. J. Agric. Food Chem. 2001, 49, 1224.

10. Murase, T.; Kume, N.; Hase, T.; Shibuya, Y.; Nishizawa, Y.; Tokimitsu, I.; Kita, T. Arterioscler. Thromb. Vasc. Biol. 1999, 19, 1412.

11. Serrano, A.; Palacios, C.; Roy, G.; Cespon, C.; Villar, M. L.; Nocito, M.; Gonzalez-Porque, P. Arch. Biochem. Biophys. 1998, 350, 49.

12. Inoue, M.; Suzuki, R.; Koide, T.; Sakaguchi, N.; Ogihara, Y.; Yabu, Y. Biochem. Biophys. Res. Commun. 1994, 204, 898.

13. Inoue, M.; Sakaguchi, N.; Isuzugawa, K.; Tani, H.; Ogihara, Y. Biol. Pharm. Bull. 2000, 23, 1153.

14. Isuzugawa, K.; Ogihara, Y.; Inoue, M. Biol. Pharm. Bull. 2001, 24, 249.

15. Palacios, C.; Cespon, C.; Martin de la Vega, C.; Roy, G.; Serrano, A.; Salinas, M.; Gonzalez-Porque, P. J. Enzyme. Inhib. 2001, 16, 527.

16. Van Besien, E.; Marques, M. P. M. J. Molec. Struct. (Theochem) 2003, 625, 265.

17. Fiuza, S. M.; Van Besien, E.; Milhazes, N.; Borges, F.; Marques, M. P. M. J. Molec. Struct. 2004, 693(1-3), 103.

18. Jeffrey, G. A.; Yeon, Y. Acta Cryst. 1990, B46, 519.

19. Okabe, N.; Kyoyama, H. Acta Cryst. 2002, E58, 245.

20. Okabe, N.; Kyoyama, H. Acta Cryst. 2002, E58, 442.

21. Másaki, H.; Okamato, N.; Sakaki, S.; Sakurai, H. Biol. Pharm. Bull. 1997, 20, 304.

22. Nam, N.; You, Y.; Kim, Y.; Hong, D.; Kim, H.; Ahn, B. Z. Bioorg. Med. Chem. Lett. 2001, 11, 1173.

23. Abe, I.; Kashiwagi, Y.; Noguchi, H. Bioorg. Med. Chem. Lett. 2000, 10, 2525.

24. Huang, M. T.; Ma, W.; Yen, P.; Xie, J. G.; Han, J.; Frenkel, K.; Grunberger, D.; Conney, A. H. Carcinogenesis 1996, 17, 761.

25. Gomes, C. A.; Girão da Cruz, M. T.; Andrade, J. L.; Milhazes, N.; Borges, F.; Marques, M. P. M. J. Med. Chem. 2003, 46, 5395.

26. Gunckel, S.; Santander, P.; Cordano, G.; Ferreira, J.; Munoz, S.; Nunes-Vergara, L. J.; Squella, J. A. Chem. Biol. Interact. 1998, 114, 45.

27. Borges, M. F. M.; Pinto, M. M. M. J. Liq. Chromatogr. 1994, $17,1125$.

28. Silva, F. A. M.; Borges, F.; Guimarães, C.; Lima, J. L. F. C.; Matos, C.; Reis, S. J. Agric. Food Chem. 2000, 48, 2122.

29. Frisch, M. J.; Trucks, G. W.; Schlegel, H. B.; Scuseria, G. E.; Robb, M. A.; Cheeseman, J. R.; Zakrzewski, V. G.; Montgomery, J. A. Jr.; Stratmann, R. E.; Burant, J. C.; Dapprich, S.; Millam, J. M.; Daniels, A. D.; Kudin, K. N.; Strain, M. C.; Farkas, O.; Tomasi, J.; Barone, V.; Cossi, M.; Cammi, R.; Mennucci, B.; Pomelli, C.; Adamo, C.; Clifford, S.; Ochterski, J.; Petersson, G. A.; Ayala, P. Y.; Cui, Q.; Morokuma, K.; Malick, D. K.; Rabuck, A. D.; Raghavachari, K.; Foresman, J. B.; Cioslowski, J.; Ortiz, J. V.; Baboul, A. G.; Stefanov, B. B.; Liu, G.; Liashenko, 
A.; Piskorz, P.; Komaromi, I.; Gomperts, R.; Martin, R. L.; Fox, D. J.; Keith, T.; Al-Laham, M. A.; Peng, C. Y.; Nanayakkara, A.; Challacombe, M.; Gill, P. M. W.; Johnson, B.; Chen, W.; Wong, M. W.; Andres, J. L.; Gonzalez, C.; Head-Gordon, M.; Replogle, E. S.; Pople, J. A. Gaussian 98, Revision A.9, Gaussian, Pittsburgh PA, USA, 1998.

30. Russo, T. V.; Martin, R. L.; Hay, P. J. J. Phys. Chem. 1995, 99, 17085.

31. Ignaczak, A.; Gomes, J. A. N. F. Chem. Phys. Lett. 1996, 257, 609 .

32. Cotton, F. A.; Feng, X. J. Am. Chem. Soc. 1997, 119, 7514.

33. Ignaczak, A.; Gomes, J. A. N. F. J. Electroanal. Chem. 1997, 420, 209.

34. Wagener, T.; Frenking, G. Inorg. Chem. 1998, 37, 1805.

35. Cotton, F. A.; Feng, X. J. Am. Chem. Soc. 1998, 120 , 3387.

36. Lee, C.; Yang, W.; Parr, R. G. Phys. Rev. 1988, B37, 785.

37. Miehlich, B.; Savin, A.; Stoll, H.; Preuss, H. Chem. Phys. Lett. 1989, 157, 200.
38. Becke, A. Phys. Rev. 1988, A38, 3098.

39. Becke, A. J. Chem. Phys. 1993, 98, 5648.

40. Hariharan, P. C.; Pople, J. A. Theor. Chim. Acta 1973, 28, 213.

41. Francl, M. M.; Pietro, W. J.; Hehre, W. J.; Binkley, J. S.; Gordon, M. S.; DeFrees, D. J.; Pople, J. A. J. Chem. Phys. 1982, 77, 3654.

42. Peng, C.; Ayala, P. Y.; Schlegel, H. B.; Frisch, M. J. Comp. Chem. 1996, 17, 49.

43. Parham, M.; Hall, L.; Kier, L. In Accurate Prediction of LogP Using E-Sate Indices with Neural Network Analysis. 220th ACS National Meeting, Washington DC, USA, 2000.

44. Slater, T. F.; Sawyer, B.; Strauli, U. D. Biochim. Biophys. Acta 1963, 77, 383.

45. Mosmann, T. J. Immunol. Meth. 1983, 65, 55.

46. Ramanathan, R.; Das, N. P.; Tan, C. H. Free Rad. Biol. Med. 1994, 16, 43

47. Rao, C. V.; Rivenson, A.; Simi, B.; Reddy, B. S. Cancer Res. 1995, 55, 259. 